$\left({ }^{1}\right.$ Centro de Engenharia Biológica - IBQF, Universidade do Minho, 4700 Braga, Portugal; ${ }^{2}$ Instituto de Estudos da Criança, Universidade do Minho, 4700 Braga, Portugal; ${ }^{3}$ Instituto de Engenharia Biomédica, Praça Coronel Pacheco 1, 4050 Porto, Portugal)

\title{
Miniaturization and application of the MTT assay to evaluate metabolic activity of protozoa in the presence of toxicants
}

\author{
N. Dias ${ }^{1,3}$, A. Nicolau ${ }^{1}$, G. S. CARVAlHO ${ }^{2,3}$, M. Mota $^{1}$ and N. LimA ${ }^{1,2}$
}

\section{(Received 28 September 1998/Accepted 27 November 1998)}

This paper describes a critical evaluation of a miniaturised colorimetric assay, using MTT (3-[4,5dimethyl-thiazol-2-yl]-2,5-diphenyl-tetrazolium bromide) reduction, applied to protozoan viability testing. The toxic substances used were copper, zinc, Triton X-100 (a membrane surfactant) and cycloheximide (an inhibitor of the protein synthesis). The viability assay of the ciliate protozoan Tetrahymena pyriformis was optimised in terms of MTT concentration and incubation time. Since protozoa are non adherent cells the MTT assay was modified in order to maintain the medium in the well. MTT proved to be effective in the measurement of Tetrahymena pyriformis viability. Four hours of MTT incubation followed by 30 minutes of incubation with DMSO were found to be the best incubation times for optical density reading. Furthermore, $10 \mathrm{mg} / \mathrm{ml}$ of MTT solution was the concentration that gave higher values of optical densities with minor medium interference.

Colorimetric assays based on tetrazolium dye reduction, as MTT, have been extensively used in the in vitro evaluation of cellular proliferation and cytotoxicity (CIAPPETI et al. 1993, CARVAlHO et al. 1996) as well as on screening for additives (COTE et al. 1993), mycotoxins (HANEL et al. 1994) or anticancer drugs (BERRIDGE and TAN 1993, LEMIEUX et al. 1993, SASAKI and PASSANITI 1998).

MTT assay is a quantitative method that consists in the metabolic reduction of the tetrazolium dye, a group of water-soluble quaternary ammonium compounds, by dehydrogenases of viable immobilised or suspended cells. Production of intensely coloured formazan water-insoluble crystals is the result of the tetrazolium reduction assay (WILSON 1995, STOWE et al. 1995, BERRIDGE et al. 1996). Formazan crystals can be either observed microscopically in the cell cytoplasm, or extracted and dissolved with organic solvents, such as DMSO, allowing spectrophotometric quantification (MOSSMAN 1983).

Suspended cells in culture do not adhere to the bottom of the well leading to a loss of cells during medium removing step and so further reading is impaired. To overcome this limitation, this paper describes a modification of the tetrazolium-based MTT assay, and the optimisation for the innovative application to free-swimming protozoa.

Being a biological indicator of wastewater, the protozoa Tetrahymena pyriformis was used in this study not only for optimisation of the MTT assay applied to suspended cells but also for the assessment of protozoa viability exposed to toxicants.

\section{Materials and methods}

Organism and medium: All toxicological assays used axenic 18-24 hours cultures of Tetrahymena pyriformis. The liquid culture medium for growth is known as PPY - Proteose Peptone Yeast Extract Medium - in the 1995 Catalogue of Strains of CCAP (Culture Collection of Algae and Proto- 
zoa, UK) and contains (g/l): Proteose peptone, 20.0; Yeast extract 2.5. All tests were performed at $20 \pm 1{ }^{\circ} \mathrm{C}$.

From cellular stock suspensions, the appropriate final concentrations $\left(10^{4}-10^{5}\right.$ cells $\left./ \mathrm{ml}\right)$ were adjusted by dilution with PPY medium.

Chemicals: MTT solution was prepared with 3-[4,5-dimethyl-tiazol-2-yl]-2,5 diphenyl-tetrazolium bromide (SIGMA M 5655) in aqueous solution, in three concentrations: $2.5 \mathrm{mg} / \mathrm{l} 5 \mathrm{mg} / \mathrm{l}$ and $10 \mathrm{mg} / \mathrm{l}$. Dimetyl-sulfoxide - DMSO - (SIGMA D 5879) was used as organic solvent for formazan.

Toxicants concentrations: Tetrahymena pyriformis was exposed to different concentrations of copper, zinc, Triton X-100 and cycloheximide.

Copper was used in six concentrations: $50 \mathrm{mg} / \mathrm{l}, 100 \mathrm{mg} / \mathrm{l}, 200 \mathrm{mg} / \mathrm{l}, 300 \mathrm{mg} / \mathrm{l}, 400 \mathrm{mg} / \mathrm{l}, 500 \mathrm{mg} / \mathrm{l}$, as di-hydrated copper chloride; a $\mathrm{pH}$ in the range 6.6-6.8 was obtained by addition of $0.1 \mathrm{~N} \mathrm{NaOH}$. Zinc was used in four concentrations: $50 \mathrm{mg} / \mathrm{l}, 100 \mathrm{mg} / \mathrm{l}, 200 \mathrm{mg} / \mathrm{l}$ and $300 \mathrm{mg} / \mathrm{l}$, as zinc chloride; a $\mathrm{pH}$ in the range 6.6-6.8 was obtained by addition of $0.1 \mathrm{~N} \mathrm{NaOH}$.

A control assay using sodium chloride was performed to investigate the influence of chloride on cell viability, before starting the toxicity tests. Chloride present at equimolar in zinc and copper bioassays caused no detectable effect.

Triton X - 100 (Sigma T 9284) was used in five concentrations: $12.5 \mathrm{mg} / \mathrm{l}, 25.0 \mathrm{mg} / \mathrm{l}, 37.5 \mathrm{mg} / \mathrm{l}$, $50.0 \mathrm{mg} / \mathrm{l}$ and $75.0 \mathrm{mg} / \mathrm{l}$.

Cycloheximide (SIGMA C 7698) was used in five concentrations: $0.0002 \mathrm{mg} / \mathrm{l}, 0.001 \mathrm{mg} / \mathrm{l}$, $0.01 \mathrm{mg} / \mathrm{l}, 0.1 \mathrm{mg} / \mathrm{l}$ and $1.0 \mathrm{mg} / \mathrm{l}$.

Optimisation of the MTT assay: A volume of $140 \mu \mathrm{l}$ of suspended Tetrahymena pyriformis culture $\left(10^{5} \mathrm{cells} / \mathrm{ml}\right)$ was added to each well of 96 -well microtiter plate. Then $10 \mu \mathrm{l}$ of MTT solution was added. The plate was incubated at $20^{\circ} \mathrm{C}$ for several periods of time (see below). Formazan production, due to cell respiration, was determined spectrophotometrically after the addition of $150 \mu 1$ DMSO without removing the medium. Care was taken to keep the solvent volume/reaction volume at a ratio of $1: 1$.

Optical densities were read in a spectrophotometric microtiter plate reader (ELISA) - SLT SPECTRA 1 - at $550 \mathrm{~nm}, 1 \mathrm{~min}, 30 \mathrm{~min}, 1$ hour and 18 hours after DMSO addition. For each time tested, 6 wells were used, 3 of them as control of non-specific MTT reduction: PPY medium without cells. MTT reaction was allowed to develop for $1,2,4$ or 18 hours. MTT concentrations of 2.5, 5 or $10 \mathrm{mg} / \mathrm{ml}$ were used and selected to simultaneously minimise medium interaction and give rise to appreciable tetrazolium reduction.

Drug cytotoxicity evaluation assay: The plating conditions needed to be optimised to ensure that cells were in exponential growth phase over the assay period. All assays were done in replicates of 3 wells per concentration. Toxic and cell concentrations were calculated for a total volume of $1.5 \mathrm{ml}$ of culture in each well. When cells were in exponential growth, $500 \mu \mathrm{l}$ of cell suspension $\left(10^{4}-10^{5}\right.$ cells $\left./ \mathrm{ml}\right)$ were placed into each well. Then $500 \mu \mathrm{l}$ of PPY fresh medium plus $500 \mu 1$ of toxicants were added at the appropriate concentrations. Assays with toxicants were performed at 1,24 or 48 hours in 24-well microplates. After drug exposure, cultures were tested for cell viability using the optimised MTT procedure described above: four hours of incubation with $10 \mathrm{mg} / \mathrm{ml}$ of MTT, addition of DMSO, and further $30 \mathrm{~min}$ of incubation. All assays were performed in duplicate.

\section{Results and discussion}

Determination of the optimal time for optical density reading with minor PPY interference

Recently non-radioactive methods have shown to be of great use in molecular biology (COLGAN 1993). Since MTT assay has been introduced and developed by MOSSMAN (1983), numerous adaptations have been done to serve different purposes. Standardisation of the method for each procedure must have into account factors such as medium components, $\mathrm{pH}$, incubation temperature, and organic solvents composition. In fact, modifications 
on these factors may affect the interpretation of results. Optimisation in plating conditions is needed to ensure that cells, when exposed to toxicants, are in exponential growth.

Cells in suspension, instead of cellular lines, do not adhere onto the well bottom, consequently, cell loss is inevitable when medium is removed (DIAS et al. 1997). To avoid this problem, the medium was not removed from the well. The drawback of this solution is that the PPY containing proteins interferes with the optical density reading and causs a reduction of the assay sensitivity. In order to minimise PPY interference, time stabilisation of the product end colour, incubation time and MTT concentration were optimised.

\section{Optimisation of the MTT assay}

Several incubation times were used to define the minimal incubation time that can be used without causing significant interference with PPY. Table 1 shows the optical densities of MTT-formazan produced when Tetrahymena pyriformis was incubated with various MTT concentrations $(2.5,5$ or $10 \mathrm{mg} / \mathrm{ml})$, at various incubation times $(1,2,4$ or 18 hours). Four hours of incubation with a solution of $10 \mathrm{mg} / \mathrm{mL}$ of MTT at $20^{\circ} \mathrm{C}$ were the best conditions for this assay: it is the only case where a statistical significant difference $(P \leq 0.01)$ was found between culture and PPY control samples, using the t-test.

Four incubation times with DMSO were used: $1 \mathrm{~min}, 30 \mathrm{~min}, 1$ hour and 18 hours (Fig. 1). Maximal interference was obtained 18 hours after DMSO addition, with statistical significance between culture and PPY control samples only at $P \leq 0.05$. Other incubation times were statistical significant for $P \leq 0.01$. Since a statistical significant difference $(P \leq 0.001)$ was found between the culture and PPY control samples for $30 \mathrm{~min}$ of DMSO incubation, this was the incubation time chosen for further readings.

Optimal conditions for this bioassay were found to be as follows: $10 \mathrm{mg} / \mathrm{ml} \mathrm{MTT} \mathrm{con-}$ centration, 4 hours of incubation at $20^{\circ} \mathrm{C}$, and $30 \mathrm{~min}$ of DMSO incubation before optical density reading.

Table 1

Effect of incubation time and MTT concentration on PPY interference on MTT assay

\begin{tabular}{|c|c|c|c|}
\hline \multirow{2}{*}{$\begin{array}{l}\text { Incubation } \\
\text { time }^{a)}\end{array}$} & \multicolumn{3}{|c|}{ MTT concentration (mg/l) } \\
\hline & 2.5 & 2.5 & 5.0 \\
\hline & PPY & culture & PPY \\
\hline 1 hour & $0.090 \pm 0.003$ & $0.096 \pm 0.001$ & $0.107 \pm 0.006$ \\
\hline 2 hours & $0.122 \pm 0.029$ & $0.131 \pm 0.004$ & $0.123 \pm 0.006$ \\
\hline 4 hours & $0.098 \pm 0.001$ & $0.168 \pm 0.041$ & $0.123 \pm 0.005$ \\
\hline 18 hours & $0.147 \pm 0.002$ & $0.230 \pm 0.043$ & $0.192 \pm 0.006$ \\
\hline \multirow{3}{*}{$\begin{array}{l}\text { Incubation } \\
\text { time }^{\mathrm{a}}\end{array}$} & \multicolumn{3}{|c|}{ MTT concentration (mg/l) } \\
\hline & 5.0 & 10.0 & 10.0 \\
\hline & culture & PPY & culture \\
\hline 1 hour & $0.143^{*} \pm 0.008$ & $0.118 \pm 0.001$ & $0.154 * \pm 0.007$ \\
\hline 2 hours & $0.213^{*} \pm 0.011$ & $0.119 \pm 0.006$ & $0.231^{*} \pm 0.030$ \\
\hline 4 hours & $0.179 * \pm 0.017$ & $0.155 \pm 0.003$ & $0.271^{* *} \pm 0.039$ \\
\hline 18 hours & $0.258^{*} \pm 0.019$ & $0.227 \pm 0.005$ & $0.307 * \pm 0.018$ \\
\hline
\end{tabular}

a Optical densities average and standard deviation of three independent assays

* Significance $P \leq 0.05$ between PPY control and culture samples

** Significance $P \leq 0.01$ between PPY control and culture samples 


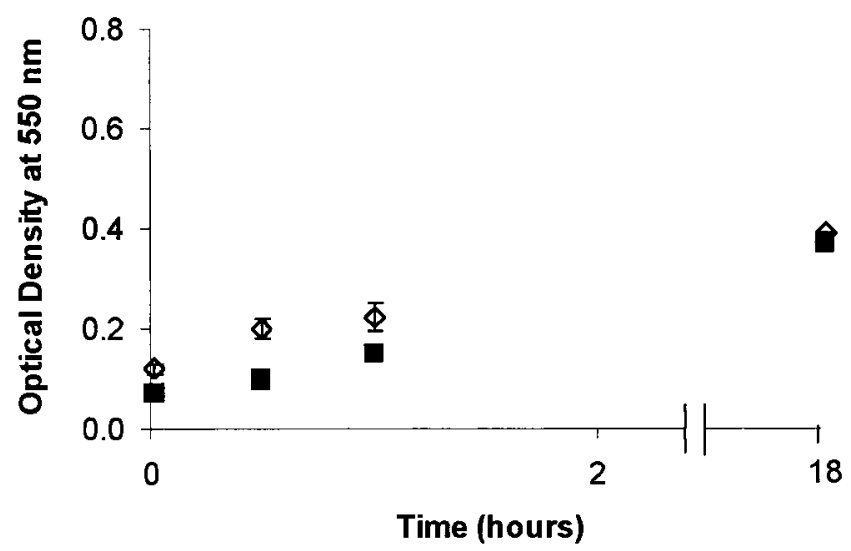

Fig. 1

MTT assay colour development in a culture of Tetrahymena pyriformis $(\diamond)$ and in PPY medium (

\section{Application of the MTT assay for Tetrahymena pyriformis viability following toxicants exposition}

The application of the method was performed exposing a culture of Tetrahymena pyriformis to copper, zinc, Triton X-100 and cycloheximide. Bioassays were performed during 48 hours, as described in Materials and Methods. Toxicants were added, in various concentrations, after 18-24 hours of culture growth. In order to determine the effects of drugs in Tetrahymena pyriformis culture, optical densities are presented as a function of cultivation time.

Copper and zinc showed heavier effects than the other drugs (Fig. 2A and 2B): after 24 hours of treatment metabolic affection on cells was visible $(P \leq 0.05$ for all concentrations of copper and zinc). For copper, there was not a detectable effect between control and $50 \mathrm{mg} / \mathrm{l}$ concentration, after 48 hours of incubation, which suggests an adaptation to the toxicant. Zinc seems to be more toxic than copper since at a concentration of $50 \mathrm{mg} / \mathrm{l}$, cells with zinc treatment showed an effective decrease in metabolic activity still after 48 hours of incubation $(P \leq 0.05)$ and it affects cell viability above $300 \mathrm{mg} / \mathrm{l}$ just one hour after exposure $(P \leq 0.05)$.

Triton X-100 (Fig. 2C) affects cell viability drastically above $50 \mathrm{mg} / \mathrm{l}$. Below this concentration, cell viability is affected only after a 24 hours period of culture in presence of the detergent $(P \leq 0.05)$. Since initial action of Triton X-100 involves extraction of proteins but not rupture of cell membranes (STOWE et al. 1995), this could explain the minor effects on cells at lower concentrations and during a short period of treatment.

Cycloheximide, an antibiotic that inhibits protein synthesis (Fig. 2D) showed, like Triton $\mathrm{X}-100$, minor effects on cell viability during the first 24 hours of treatment: only $1.0 \mathrm{mg} / \mathrm{l}$ affects metabolic activity significantly $(P \leq 0.05)$. Cell viability increased after 48 hours of drug treatment at $0.0002 \mathrm{mg} / \mathrm{l}$ and $0.001 \mathrm{mg} / \mathrm{l}$ levels $(P \leq 0.05)$. ROBERTS and ORIAS $(1973)$ refer to the unique capacity of Tetrahymena pyriformis cells to adapt to the presence of drugs, including cycloheximide, at initially inhibitory concentrations, but no reports were found about stimulation of metabolic activity. After 48 hours of exposure to cycloheximide, cell viability decreased significantly $(P \leq 0.05)$ for the concentrations of $0.1 \mathrm{mg} / \mathrm{l}$ and $1.0 \mathrm{mg} / \mathrm{l}$

Summarising, copper and zinc treatment showed visible effects 24 hours after toxicant addition whereas for Triton X-100 and cycloheximide, major effects being detectable only 48 hours after drug treatment. 

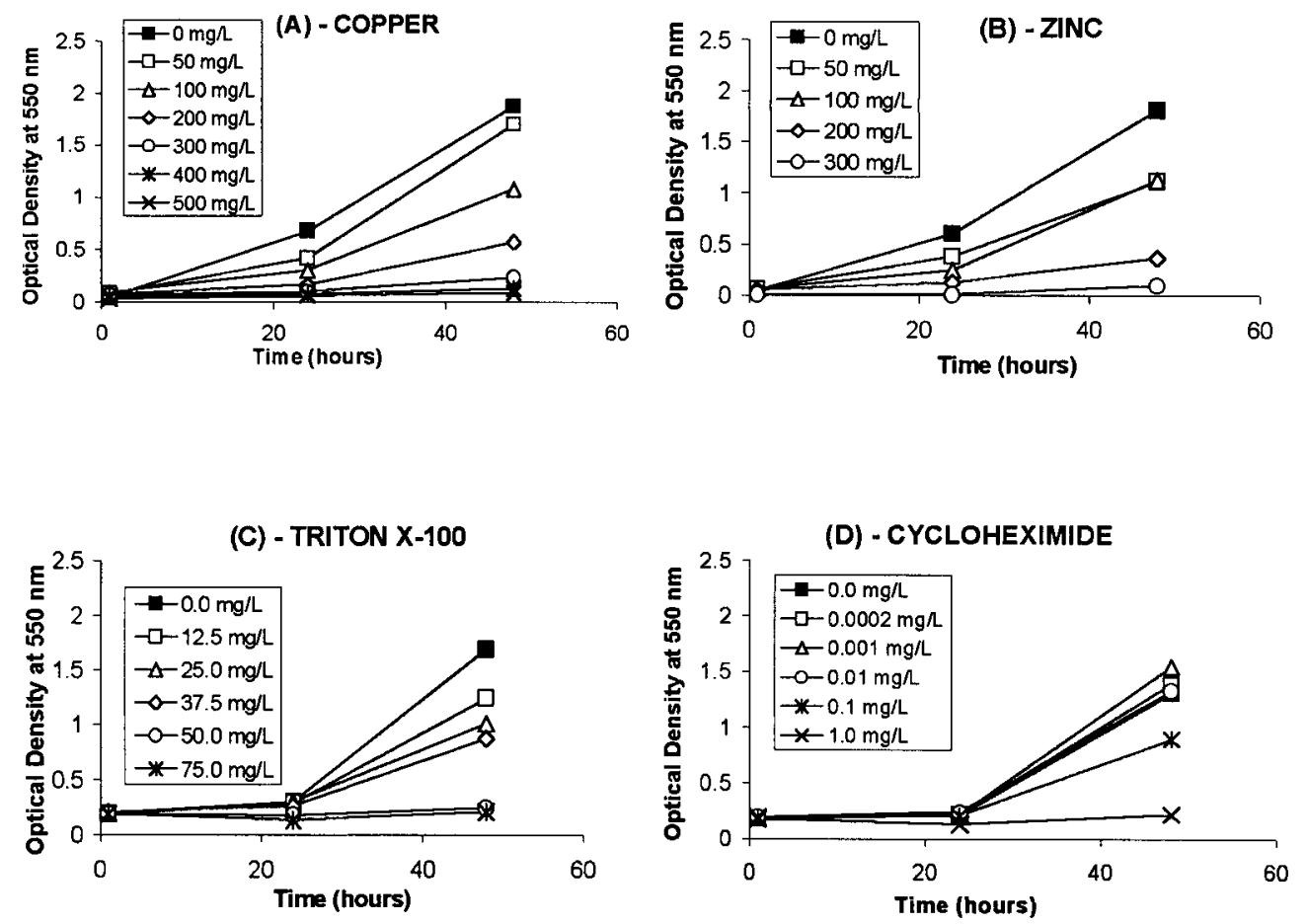

Fig. 2

Effects of copper (A), zinc (B), Triton X-100 (C) and cycloheximide (D) concentrations on MTT reduction, after drug treatment

Conventional toxicological assays are often slow and labour-intensive, and become impractical when many compounds and/or concentrations are being tested rapidly. This has led to a greater interest in colorimetric and fluorimetric assays which can be miniaturised in 96-well microtiter plates and assessed using an ELISA spectrophotometric microtiter plate reader (MARTIN and CLYNES 1993). In this aspect, the MTT assay and the use of protozoa seems an excellent option: it allows simultaneous tests of different toxicants at various concentrations and even in this case is rapid and does not require the technical expertise nor the operational expenses of some of the standardised bioassays.

\section{Acknowledgements}

NiCOLINA Dias and ANA NicolaU were supported by grants BM/4291/97 and BD/5080/95 from PRAXIS XXI, respectively. This project was supported by a PRAXIS XXI- 2/2.1/ BIO/ 1118/ 95 contract.

\section{References}

BERRIDGE, M. V. and TAN, S., 1993. Characterization of the cellular reduction of using 3-[4,5dimethyl-thiazol-2-yl]-2,5-diphenyl-tetrazolium bromide-MTT): Subcellular localization, substrate dependence, and involvement of mitochondrial electron transport in MTT reduction. Arch. Biochem. Biophysics, 303, 474-482. 
Berridge, M. V., TAN, S., McCoy, K. D. and WANG, R., 1996. The biochemical and cellular basis of cell proliferation assays that use tetrazolium salts. Biochemica, 4, 15-20.

Carvalho, G. S., Castanheira, M., Diogo, I., Abreu, A. M., Sousa, J. P., Loon, J. A. and Van BLITTERSWIJK, C. A., 1996. Inhibition and stimulation of enzymatic activities of human fibroblasts by corrosion products and metal salts. J. Mat. Science: Mat. in Medicine, 7, 77-83.

Ciappeti, G., Cenni, E., Pratelli, L. and Pizzoferrato, A., 1993. In vitro evaluation of cell/biomaterial interaction by MTT assay. Biomaterials, 14, 359-364.

ColGan, D. J., 1993. Spectrophotometric quantitation of DNA on blots after ethanol-solubilization of the MTT-formazan from anti-digoxigenin-based detection of nucleic acids. Appl. Theor. Electrophoresis, 3, 219-222.

Cote, J., KAMEN, A. A. and Andre, G., 1993. Protein-free culture medium improvement. Testing additives and their interactive effects in 96-well plates. Appl. Microb. Biotechnol., 39, 577-584.

Dias, N., Lima, N., Carvalho, G. S. and Mota, M., 1997. Miniaturização do ensaio do MTT para avaliação da actividade metabólica dos protozoários. Congresso Nacional de MicrobiologiaMICRO' 97, Tomar.

Hanel, T., Gareis, M. and KollarcziK, B., 1994. Citotoxicity of mycotoxins evaluated by the MTT-cell culture Assay. Mycopathologia, 128, 167-174.

Lemieux, P., Michaud, M. and Pagé, M., 1993. A new formazan amplified clonogenic assay for cytotoxicity testing. Biotechnol. Techniques, 7, 597-602.

Martin, A. and Clynes, C., 1993. Comparison of 5 microplate assays for in vitro cytotoxicity testing and cell proliferation assays. Cytotechnology, 11, 49-58.

Mossman, T., 1983. Rapid colorimetric assay for cellular growth and survival: application to proliferation and cytotoxicity assays. J. Immunol. Methods, 65, 55-63.

RoBERTS, CH. T. and ORIAS, E., 1973. A cycloheximide-resistant mutant of Tetrahymena pyriformis. Exp. Cell Res., 81, 312-316.

SASAKI, C. Y. and PASSANITI, A., 1998. Identification of anti-invasive but noncytotoxic chemotherapeutic agents using the tetrazolium dye MTT to quantitative viable cells in matrigel. BioTechniques, 24, 1038-1043.

Stowe, R. P., Koenig, D. W., Mishra, S. K. and Pierson, D. L., 1995. Non destructive and continuous spectrophotometric measurement of cell respiration using a tetrazolium-formazan microemulsion. J. Microbiol. Methods, 22, 283-292.

WILSON, A. P., 1995. Citotoxicity and viability assays. In: Animal Cell Culture - A Practical Approach. 2nd ed., (R. I. FRESHNEY, Editor), pp. 277-289. Oxford University Press, Oxford.

Mailing address: Prof. Dr. N. LimA, Centro de Engenharia Biológica, Universidade do Minho, 4700 Braga, Portugal

e-mail: nelson@iec.uminho.pt. 